\title{
Legislation and Equality in Basic Education for All in China
}

\author{
Wing-Wah Law and Su-Yan Pan \\ The University of Hong Kong
}

\begin{abstract}
With reference to compulsory schooling legislation in China, this article examines the functions of and the constraints on using law to institutionalize equality in basic education. It argues that, in China, law is a last resort, holding governments of various levels accountable. Law can be a device of social justice to promote equity in education by serving as an important mechanism to check and balance the state's power as regards its obligations towards instituting basic education, redistributing public resources, and reducing disparities and promoting equality in compulsory schooling. However, the use of legislation to promote equity in basic education is constrained by economic conditions and other extra-legal factors. This article concludes by offering an explanation of the functions of and constraints on law in the quest for equality in basic education, as well as the implications of China's experience for understanding law and change.
\end{abstract}

KEYWORDS: Educational equality, education for all, legislation, law, state, social change, China

\section{Introduction}

Despite its different meanings and manifestations, the principle of equality has been used to confront social inequalities in a variety of stratified societies and cultures. While the United Nations (UN) is striving for universal primary education for children across the globe by 2015 (UN Millennium Project, 2005), educational inequality persists and has become a significant challenge for educational policymakers, scholars, and practitioners worldwide (Gopinathana \& Altbach, 2005). Yet, three phenomena related to this issue have been underresearched: problems arising because of the use of economic strategies to implement policies on universal basic education; increased legislative emphasis on regulating governments' behavior to ensure equality in basic education; and socio-cultural and economic constraints on using law to facilitate educational changes for promoting equity in basic education. This article seeks to fill this gap.

With reference to compulsory schooling legislation, this article argues that, in China, law is used in policymaking as a pragmatic instrument to address specific educational problems, and as a last resort, holds governments of various levels accountable for improving education. In doing so, law can be a device of social justice to promote equality in education by serving as an important mechanism to check and balance the state's power as regards its obligations towards providing basic education, redistributing public resources, and reducing disparities and promoting equality in compulsory schooling. However, using legislation to promote equity in basic education is constrained by economic conditions and other extralegal factors. Effecting change requires favorable economic, social, and cultural conditions, as well as the cooperation of those who interpret and enforce the law.

To present the argument, we first review literature concerned with the concept of equality and basic education for all, to provide a framework for explaining legislation as a means to ensure equality in compulsory schooling. We then present the strategies of China's state to implement nine-year compulsory schooling, and the consequential problems of 
inequality between and within schools across the country. This is followed by an examination of how compulsory schooling legislation was revised, focusing on the complex issue of increasing educational disparities and inequality. The article concludes by discussing the functions of and constraints on law in the quest for equality in basic education in China, and the implications of China's experience for understanding law and change.

\section{Equality, Basic Education for All, and Legislation}

In many countries, legislation has been used as a major means to institutionalize the principle of equality in education and society. The pursuit of equality has been a long-standing political aspiration in human history (Nash, 2004). Equality can be considered as an important principle of governance in the pursuit of an egalitarian society. Le Grand (1982) suggested that, to achieve an egalitarian society, social policy should cover five areas of equality. As summarized by Jary and Jary (1999), these areas include equality of public expenditure, equality of final income, equality of use of service, equality of outcome, and equality of opportunity. Among them, the concept of equality of opportunity is most fundamental and indicates that regardless of class, age, race, or gender, all people "should have equal rights to compete for and attain sought-after positions in society" (Jary \& Jary, 1999, p. 202).

Many sociological and educational studies have discussed the relation between equality and education. For example, Horton and Hunt (1984) argued that in modern society, people are given status or rewards according to their merits, which are often measured by results of schooling, and in turn can affect individuals' life chances. Dahrendorf (1975) considered education as an important vehicle of social mobility in stratified society and equal educational opportunity as a basic right of every person. Levin (1976) expanded the meaning of educational equality to include: equality of educational access, equality of educational participation, equality of educational results, and equality of educational effects on life chances. Equality of opportunity within education, as Bilton et al. (2002) argued, needs to be ensured so that opportunities for success in school are the same for everyone with similar abilities, regardless of sex, ethnicity, and socioeconomic background. Iannelli and Paterson (2007, p. 231) concluded, however, that the social project of "using education to equalize life chances has been a failure." They even argued that education "cannot be used, on its own, to eradicate social inequalities, and is relatively powerless to counter the middle-class strengths of effective networks, self-confident aspirations and sheer wealth."

Despite the debate, the provision of basic education for all with a minimum period of schooling is still believed to be a vital means for reducing inequality within and between societies. Since World War II, the UN has advocated a rights-based approach to basic education. In the Universal Declaration of Human Rights, the UN (1948, Article 26) declared that "[e]veryone has the right to education" and that education shall be "free" and "compulsory," at least during the elementary and fundamental stages. This right can empower individuals to achieve "the goals of personal autonomy and efficacy" and enable them to determine the course of their lives (Donnelly \& Howard, 1988, p. 235). In the Jomtien Declaration, which marked the beginning of the movement of education for all, UNESCO (1990) reaffirmed education as a fundamental right for all people regardless of their gender or age.

In response to these global aspirations, many countries have adopted strategies to provide basic education for all. Of these strategies, compulsory schooling legislation is a particularly common one. Legislation can compel the state to provide eligible children with free basic education for a minimum period of, for example, six or nine years and compel parents to send their children to school. As a result, despite such problems as gender disparity, the number of children in the world enrolled in primary school increased by $6 \%$ to 688 million 
from 1999 to 2005, and the number of children out of school dropped from 96 million in 1999 to 72 million in 2005 (UNESCO, 2007).

However, providing and legislating compulsory schooling does not necessarily mean the complete eradication of educational inequalities in compulsory schooling. Many studies have shown that inequality in school education continues to exist in many forms. As noted by Coleman (1966, 1975, 1990), Jencks (1972), Levin (1976), and Ballantine (2001), they include: inequalities in educational input and output, and educational opportunity and life chances for children of different social groups, for boys and girls, and for local and non-local students. Inequality of students' academic performance can be caused by many factors, such as cultural practices, social class, family background, ethnicity, gender, and sexuality (Coleman, 1990; Darling-Hammond, 2007; Lynch \& Moran, 2006).

Using legislation as a means to institutionalize equality in basic education is part of an international trend of increasing reliance on legislation to bring about social change (Dalal, 2005; Nagel, 1970; Summers, Campbell, \& Hubbard, 1974; Ziegel, 1973). As summarized by Anleu (2000), one extreme view sees law as an appropriate instrument of effecting social change, a way for governments to implement programs and reforms and for activists to promote their social agendas. Those at the other end of the spectrum dismiss legislation as an ineffective effort to engage in social change or alter social practices. As Hazard and Rosenblum (1976, p. 261) explained, the effect of law is limited because law and lawmakers are not "equipped to solve essentially human problems of complex, subtle, and often delicate" problems in education and society.

Since the late 1980s, China has been caught in such a dilemma in the legislation of compulsory schooling. Following the economic reforms of the late 1970s, China began to use law as an instrument to reform and regain control over the economy, society, and education (e.g., Law, 1999; J. F. Li, 2007; Wang, 2000). The ruling Communist Party of China (CPC) adopted the principle of governance according to the rule of law as a central strategy for national development (National Congress of the Communist Party of China, 2002). Applying this principle to educational reform, China enacted several major laws and many regulations intended to effect educational changes, promote good educational practices, and address the changing relationships among the state, the market, society, and education (Law, 2002). In 1986, China enacted its Basic Education Law and began to provide nine years of compulsory schooling. According to Zhang and Zhao (2006), the 1986 law helped China universalize its basic education in terms of high student enrolment. However, the strategies for universal basic education used in the 1980s gave rise to problems associated with the quality and equality of basic education. To address these problems, Chinese lawmaking bodies were strongly urged to revise the Basic Education Law.

The general literature on equality, basic education for all, and law can help explain the function of and constraints on legislation to ensure equality in basic education in China. However, it cannot explain three specific phenomena: educational inequality as a consequence of the state's strategies to achieve universal basic education; increased legislative emphasis on regulating government's behavior to ensure equality in basic education; and the socio-cultural and economic constraints on the use of law to facilitate educational changes for promoting equity in basic education across the nation. This article attempts to fill in this gap. To approach these issues, it is useful to understand the general background for universal basic education in China.

\section{Basic Education in China: Its Rationale, Strategies, and Achievements}

China has a population of about 1.3 billion that comprises 56 ethnic groups: Hans is the ethnic majority (about $92 \%$ of the population), and there are another 55 ethnic minority groups (about 8\%), mainly distributed in the western part (such as Guangxi, Guizhou, 
Qinghai, Tibet, and Xinjiang). In the 1980s, the provision of nine-year, compulsory basic education was more of a strategy that the state used to support domestic economic development than an expression of concern about people's rights and freedoms or a response to UNESCO's call for universal basic education. In the late 1970s, China's state adopted a two-pronged approach to enhancing its national strength in a global age. Internationally, China diversified its economic ties to include capitalist countries, joined the World Trade Organization (WTO) in 2002, and increased its participation in international affairs, as well as its competition for global capital.

Domestically, while emphasizing the overriding significance of political and social stability, China's state used four major strategies to revive its declining socialist economy and modernize the nation. First, the state began to decentralize authority and financial responsibility to lower levels of governance and spread this authority among different stakeholders, including allowing the participation of private forces and the use of market principles in the centrally planned economy, with a view to promoting efficiency and creating competition between institutions and among individuals (Law, 2006). Second, it deliberately implemented a policy of unbalanced development (Yu, 2004). In particular, it allowed some areas (such as special economic zones) and people to get rich first, with a view to utilizing them to alleviate poverty, particularly in rural areas, and thereby promote co-prosperity across the nation (Deng, 1991; Jiang, 1997). Third, China's state rebuilt the legal system and reinstated the rule of law in governing the nation and regulating the new relationships and practices arising from economic reforms (Law, 2002). According to the Constitution (1982), the National People's Congress (NPC) is the highest law-making body at the national level and has the power to make national laws, while the State Council and its ministries have legislative power to make the administrative regulations necessary to enforce, interpret, and supervise the law.

Lastly, associated with the first three strategies, the state translated manpower needs for economic modernization into demands on education. China's national leaders, including Deng Xiaoping (1977a, 1977b, 1978), Jiang Zemin (2002), and Hu Jintao (2006), repeatedly emphasized the importance of education for improving the quality of China's workforce and enhancing its national strength in international competition. In the 1980s, China introduced a series of initiatives to expand and reform its entire educational system, ranging from primary education to higher education, with a view to providing different tiers of the labor market with qualified workers with relevant academic qualifications and vocational skills (Communist Party of China Central Committee, 1985). Of these initiatives, Chinese leaders saw the provision of nine-year compulsory schooling (i.e., primary and junior-secondary education) across the nation as a most important task, because it was expected to train people with basic literacy to serve at the lower, but largest stratum of the labor market (Communist Party of China Central Committee and State Council, 1993). Therefore, of all levels of education, basic education was the first selected for expansion.

As a result of these economic considerations, the state adopted three strategies to popularize basic education across the country that were similar to those used in the economic revival. The first strategy was to rely on the law to make nine-year schooling compulsory. According to the former State Education Commissioner Li Peng (1986), in many rural areas, the popularization of primary education was not realized and a large portion of children, particularly girls, could not finish primary education. In some cities and towns, the dropout rates of junior-secondary students remained high. Child labor was not uncommon. To address these issues, China enacted two laws: the 1986 Basic Education Law to make nine-year schooling compulsory, and the law in 1991 to protect minors and prohibit the employment of children under age 16 (National People's Congress, 1986, 1991). The law adopted a rightsbased approach by spelling out five fundamental principles to achieve universal basic 
education in China, including: an ideological goal of basic education for training socialist constructors and successors (Article 3); the principle of equal educational opportunity for all eligible children to have at least nine years of schooling, regardless of, for example, physical conditions, gender, ethnicity, and family background (Articles 4, 5); the policy of examination-free admission by school networks (Article 9); the legal obligation of parents or guardians to send their eligible children to school; and the prohibition of child labor (Articles $11,15)$.

The second strategy was to regionalize the promotion of universal basic education, which can be seen as an extension of the economic strategy of unbalanced development, letting some areas and people get rich first with education. China's state divided the nation into three regions (eastern, middle, and western) and set different goals for universal basic education to be achieved in stages, according to the region's economic and cultural conditions (Communist Party of China Central Committee, 1985). The initiative was planned to be achieved mainly in one quarter of the population in comparatively more economically developed cities and provinces, mainly in the eastern (coastal) region by the end of 1980s, then in half of the population in the mid-level developed areas (mainly in the middle region) by the mid-1990s, and finally in the remaining one quarter of the population in the least developed areas (mainly in the western region, where most ethnic minorities live) in the early 2000s.

The third strategy was to decentralize administrative and financial responsibilities from the central government (the State Council) to local (difang) governments. Local governments comprise four sublevels: provincial (highest local level), city or county, district or township, and village (lowest). In the early 1990s, local governments began to directly administer their basic education and bear the major financial responsibility for it (State Council, 1994, 2002a). In particular, the county and township governments were responsible, respectively, for salary-related items and daily operation costs (including maintenance) of their schools (Y. R. Liu, 2003). Provincial governments and the central government supported mainly higher education. They also provided strong support for school education on a regular basis in very poor areas and ethnic minority areas such as Tibet, but subsidized schools in other areas mainly through special, though irregular funds on given items (zhuanyi zhifu), such as the scheme for rebuilding dilapidated school buildings (see the details about these schemes in T. D. Zhang \& Zhao, 2006).

The years since the 1980s have witnessed remarkable economic achievements in China. Between 2000 and 2005, China significantly increased its Gross Domestic Product (GDP) from RMB 9.9 trillion to RMB 18.2 trillion and its per capita GDP from about RMB 7,860 (US\$950) to RMB 14,000 (US\$1,700) (National Bureau of Statistics, 2006b). Moreover, economic reform quickened the pace of industrialization and urbanization. However, since the 1990s, domestic economic policies promoting market forces and unbalanced development have led to intensified social conflicts and unrest, as well as a widening income gap between rich and poor and regional economic divides among the eastern, middle, and western parts of China (Dittmer, 2003; Lewis \& Xue, 2003; Tang, 2001).

Similar occurrences can be seen in the country's basic education system. To a large extent, economic strategies helped China resolve the demand for access to basic education for all. Between 1985 and 2006, the admission rates of the primary-school age cohort and the junior-secondary cohort rose from $95.9 \%$ to $99.3 \%$ and from $53.5 \%$ to $97 \%$, respectively (Ministry of Education, 2007a). This means that China achieved the provision of nine-year compulsory schooling earlier and better than the millennium goal of having all children able to complete a full course of primary schooling by 2015 (World Bank, 2002). Despite quantitative achievements in access, the problems of inequality arising from such economic strategies were also refracted into and reflected from basic education. 


\section{Inequalities in China's Basic Education}

The problems of inequality in China's basic education system are characterized by three related features: the uneven distribution of financial resources resulting from a mismatch between the financing responsibility and the financial ability of governments at various levels, the widening of inter- and intra-school disparities and therefore inequality of educational opportunity for students in educational input and participation, and inequalities confronting education for domestic migrant workers' children and ethnic minority children.

Uneven Distribution of Financial Resources

In China, the uneven distribution of financial resources results from a mismatch between the financing responsibility and the financial ability of governments at various levels. The 1986 Basic Education Law prescribed a system of "level-by-level local responsibility and management" of basic education and vaguely spelt out state and local governments' financial responsibilities for the recurrent and non-recurrent costs of basic education (National People's Congress, 1986, Articles 8 and 12). It stipulated that the state's growth in its budgetary appropriation for basic education should be higher than the growth of its recurrent revenue, and it allowed local governments to levy education-specific taxes that would be used mainly for basic education. However, the old law did not delineate clearly the relative share between the state and local governments of various levels in financing basic education.

Using this legal ambiguity, China's state, as mentioned earlier, adopted a strategy for devolving administrative and financing responsibilities for compulsory schooling to local governments. In the 1980s and early 1990s, this strategy was successful because local governments had better revenues than the central government. However, the landscape changed after the 1994 reform of the financial system and taxation by increasing the state's share of local taxes with local governments (see the complexity of this reform in L. C. L. Li, 2006). The central government became better off, while local governments were worse off. For example, of the total government revenue of RMB 1,340 billion in 2000, the shares of the central government, provincial governments, prefectural governments, and county and township governments were $51 \%, 10 \%, 17 \%$, and $22 \%$, respectively (Q. Zhang, Zhang, Zhong, Zhu, \& Su, 2004).

In spite of this change in financial ability, township governments continued to be responsible for financing basic education until a policy of reliance on county governments was adopted in 2002. Of the country's total basic education expenditure in 2000, township governments accounted for $78 \%$; county governments, 9\%; provincial governments, $11 \%$; and the central government, 2\% (Q. Zhang, et al., 2004). Local governments in urban and coastal areas (such as Shanghai) have greater financial revenues and therefore higher abilities for basic education, while the governments of many townships and counties in less-developed or slower-developing rural areas, particularly those in the central and western parts of China (such as Gansu and Guizhou Provinces) have difficulty financing their schools.

\section{Unequal Opportunity of Educational Input and Educational Participation}

The mismatch between financial ability and responsibilities for basic education, compounded with the continuously low public educational investment in education, caused an additional problem: the widening of inter- and intra-school disparities in basic education and therefore unequal educational opportunities for students. In basic education (and postcompulsory education), rich schools have tended to become richer and poor schools have remained poor, with three major types of disparities. The first type of disparity is interprovincial. Between 1995-96 and 2006-07, the ratio of the highest to lowest expenditure of budgetary appropriation for education per student rose from 8.5 to 10.7 in primary education and from 4.9 to 9.3 in junior-secondary education (calculated from Ministry of Education, 
National Bureau of Statistics, \& Ministry of Finance, 2006; State Education Commission, 1997).

The second type is an urban-rural disparity. About $70 \%$ of basic education students live in rural areas, but public investment in rural basic education has lagged behind that in urban areas. In 2001, the per-capita education expenditures for primary and junior-secondary students were, respectively, RMB 1,484 and RMB 1,955 in cities and towns, and RMB 798 and RMB 1,014 in rural areas (Project Team of a Case Study on Key Educational Policy in Transitional China, 2005). Over $80 \%$ of dilapidated primary school buildings were in rural areas. In 2002, the percentages of qualified, regular teachers in cities were about $10 \%$ higher than those in rural areas. Moreover, the disparity in quality of teachers was exacerbated by an imbalanced flow of teachers. Because of conspicuous differences in income and working conditions, the flow of teachers was mainly unidirectional: from rural to urban, from poor to rich areas, and from ordinary to keypoint schools; and those who move "upward" have been mainly those who are recognized as excellent teachers (J. Chen \& Chen, 2008).

The third type is an inter-school disparity within the same area. Similar to the strategy of letting some areas and people get rich first in the economic sector, the patriarch Deng Xiaoping (1978) strongly advocated the development of keypoint schools and universities as a national policy to quicken the enhancement of the workforce. As a result, local resources from the government and communities were tilted towards upgrading a few existing schools to keypoint schools or establishing new keypoint schools under various names, such as "experimental" (shi yan) or "demonstration" (shi fan) schools.

In addition to these three interschool gaps, there are intra-school disparities. It is not uncommon for schools to stream students according to their academic performance. Students who perform well academically have a better chance of going to keypoint or "fast" classes (kuai ban, for which there are other terms such as "elite" or "talent" classes), whereas students with ordinary or poor academic performance are allocated to ordinary or "slow" classes (man ban). Schools commonly justify their streaming policies by claiming a need to cater to students' different learning abilities. However, many schools tilt resources towards students in keypoint classes (e.g., by arranging for them to have good teachers and providing them with more opportunities for learning, competition, and exposure) so as to help students attain higher examination scores and thus enhance the school's reputation. On top of academic scores, students must pay an additional class-choice fee for a place in a keypoint class, for example, RMB 10,000 - RMB 30,000 in some schools in Beijing (X. S. Yang, 2005).

These disparities have resulted in unequal educational input to schools and unequal educational opportunities for individual students. As compared with their counterparts from urban, rich provinces, and "fast" classes, students from rural, poor provinces, and "slow" classes receive fewer educational resources and are hindered from full and equal participation in education. In addition, China has seen the emergence of another two educational problems: the adverse effect of the heavy study load and examination pressure on the quality of teaching and learning and the heavy financial burden of widespread fee abuse on students and their parents (Law, 2007). In June 2006 the state confirmed its belief in revising the Basic Education Law to address these problems and effect educational changes.

\section{Educational Inequalities Confronting Migrant Workers' Students and Minority Students}

Equal educational opportunity in compulsory schooling in China was further confronted by problems arising from uneven paces of modernization and urbanization across the nation beginning in the 1980s. This resulted in surplus rural labour and an unprecedented, large-scale domestic migration of workers from less to more developing areas, such as Beijing, Guangdong, and Shanghai. The population of migrant workers increased from 93 million in 2000 to 147 million in 2005; over $30 \%$ of the latter were cross-provincial migrants 
(National Bureau of Statistics, 2006a; State Council, 2002b). In host places, a majority of these migrant workers were unskilled labourers and earned low incomes by working in, for example, factories and construction sites. After settling down, many single migrant workers married and had children. Other migrant workers who were already married brought their families to their working cities. It was estimated that the number of migrant children under age 18 increased from 2 million in 2000 to 20 million in early 2004 (D. Liu \& Wang, 2004).

Despite their parents' contribution to local developments in their new domicile, migrant children, unlike their local counterparts, were deprived of an equal opportunity to access public schools. First, they were not entitled to access free basic education in the host domicile, owing to the household registration policy ( $h u$ kou zhi du), which was enacted in the late 1950s (National People's Congress Standing Committee, 1958). This policy aimed to restrict the flow of people from rural to urban areas by broadly dividing the population into agricultural and non-agricultural sectors and linking domicile registration to employment, housing, health care, and other forms of social welfare that were provided mainly by local governments (Law, 2006; Wu \& Treiman, 2003).

Second, host local governments were not willing to finance basic education for migrant students; nor were the original local governments, which argued that migrant students were no longer in their jurisdictions. Many host public schools were also not willing to admit migrant children because of a lack of local government subsidies and worries about a possible drop in overall student academic performance. If they admitted migrant children, they charged "school-place rental fees" and other miscellaneous fees.

Third, the task of educating migrant children fell on illegal migrant workers' schools, which began to flourish in the 1990s. The number of migrant workers' schools in Beijing increased from 1 in 1993 to 144 in 1999 and 241 (enrolling about one third of all migrant children) in 2006 (Wen, 2007). Most illegal migrant workers' schools had serious fire safety and hygiene problems and were equipped with unqualified teaching staff and sub-standard facilities (Kwong, 2004; Wen, 2007). Nevertheless, most migrant parents preferred to send their children to illegal migrant workers' schools largely because of fee differences. For example, in the early 2000s, public schools in Beijing charged migrant children RMB1,100 RMB2,600 per semester for school-place rental fees and miscellaneous fees, whereas migrant workers' schools charged about RMB300-RMB600 (Wen, 2007).

Unlike migrant workers' children, who have been marginalized, children of ethnic minorities have been forced to integrate with the majority culture through public education. As long as ethnic minorities did not threaten the political power of the ruling party and territorial integrity, China's state has allowed them a certain amount of autonomy (such as some political control over their own areas, appointment of ethnic minority members to hold political positions, and keeping their own religions, cultures, and languages in daily life) (Mackerras, 1995). The national policy of universal basic education greatly improved the likelihood that children in ethnic minority areas would receive nine-year schooling.

However, providing basic education in ethnic minority areas has been a challenge. Limited public financing has widened school disparities between and within areas. Also, despite the national policy of one child, many ethnic minority families had more children, and therefore a larger financial burden for their children's education, which contributed to higher dropout and retention rates, as well as lower rates of admission and promotion to next level of education (H. Yang, 2006). Finally, despite the toleration of ethnic minority cultures and bilingualism, the China's education policy for ethnic minorities has used a unified national curriculum, and promoted learning Chinese and speaking the national oral language (i.e., Putonghua), particularly on public occasions, which reinforced the Han cultural capital, rather than their own (Postiglione, Jiao, \& Gyatso, 2005). 


\section{Revision of the Basic Education Law}

China's highest lawmaking body, the NPC, revised the Basic Education Law to deal with issues of inequality in basic education by giving it two new missions: to hold the government accountable for ensuring a fair educational system and to extend the level of equity beyond the right to equal access to include the entitlement of equal opportunity to learn. These two missions were motivated by (a) the national development goal and (b) loopholes originating in the original law. As mentioned above, since the 1990s, domestic economic policies promoting market forces and unbalanced development have led to increasing inequalities in wealth distribution and therefore an intensification of social conflicts and unrest. To rectify these problems and pacify citizens since their assumption of power in the early 2000s, President Hu Jintao (2003, 2007, 2008) and the State Council (2004) under Premier Wen Jiabao repeatedly emphasized the importance of social equity and justice to social stability. In this context, reducing inequality and promoting equity became concerns in national education reform, as well as an increasingly important topic of discussion in educational policymaking (Chu \& Yang, 2008; Zhai, 2008).

The second motivation, to close loopholes in the original law, came to awareness because the law could not cope with emerging problems of inequality and disparity arising from other social and educational changes since the economic reforms of the 1980s. These concerns were partly created and/or exacerbated by the original strategies to regionalize and decentralize administration and financing, which the law permitted and endorsed. To close the legal loopholes, a variety of groups, including lawmakers, pressed for the law's revision (Research Project on Compulsory Education Development in China, 2006). In 2003, the NPC began a legislative survey, at home and abroad, to collect views and opinions about revising the Basic Education Law. How to create a mechanism to ensure financing for basic education across the nation had been a major concern expressed by both the public and the NPC's internal discussions (Research Project on Compulsory Education Development in China, 2006).

Thus in June 2006, the NPC Standing Committee significantly revised the Basic Education Law, which continued to guard rights-based basic education for all by inheriting from the old version five fundamental principles (as presented earlier). In line with its new missions, however, the revised law included two new, major features. First, the legislation's focus shifted from how to ensure access, quantity, and efficiency in the provision of basic education to how to ensure quality, equality, and "balanced development." Second, the major target of legislation was regulating the governance of units higher than the county level, rather than lower units or other education stakeholders, such as parents and schools. Fortyone (of 63) articles are related to how to regulate the government's behaviors at various levels in the implementation of the revised law; of them, 30 articles clearly specify the responsibilities and duties of the State Council and/or people's governments above the county level, and the consequences if they fail to fulfill them.

The State Council demonstrated a high level of cooperation with the NPC before and after the revised law's passage. Immediately after the law passed, the Ministry of Education (2006b) further showed its determination to implement the revised law and issued the Opinions Concerning the Implementation of the Basic Education Law to Further Regulate School Practices in Basic Education (hereafter called Opinions) to provide specific regulations for local governments and schools. In addition to accepting more self-regulation, the State Council significantly expanded the scope of its regulation by the law.

A further analysis of the revised law and implementation regulations reveals legislation's two functions in effecting changes in China's policy of basic education: (a) providing a legal clarification for reshuffling financial responsibilities among governments of 
various levels, and (b) promoting the principle of "balanced development" to reduce inequality between and within schools, as discussed below.

Reshuffling Public Roles and Responsibilities

To rectify the mismatch problems, the revised law redefined the public roles of governments of various levels in basic education and shifted the responsibilities from the governments of lower units to higher ones. In particular, the State Council has a legal obligation to take more responsibility for financing basic education in different parts in China.

First, the revised law clearly defines the provision of basic education as the state's responsibility. Basic education is now stipulated as an "enterprise of public interest" and the state is required to "ensure" the provision of this public good (Article 2). The scope of free basic education is legally extended from the exemption of school fees to include the waiving of miscellaneous fees (Article 2), and is further broadened by an increase in subsidies for textbooks and boarding fees by governments of various levels to students with financial difficulties (Article 44). This extension gives the highest legal status to the State Council's (2005) policy of "two exemptions and one subsidy" (i.e., the waiving of school fees and miscellaneous fees, and one subsidy for textbooks and boarding).

Second, the revised law articulates a fundamental principle for redistributing responsibilities among governments of various levels. The State Council is responsible for taking a leadership role in all aspects of basic education (Article 7). At the local level, in their jurisdictions, provincial governments or the equivalent are responsible for planning and coordinating basic education, whereas county governments are responsible for its regular administration and management. The Opinions reminds provincial governments of the need to enact local regulations on implementing the revised basic education law in accordance with local conditions and needs, and setting clear "boundaries of policy" that governments of various local levels must observe.

Third, instead of relying mainly on local governments, the state is now responsible for ensuring the financing and implementation of basic education (Articles 2, 42). The state's responsibility covers three major areas: (a) the demand on provincial governments for planning and ensuring the financing for basic education in their jurisdictions, (b) the general co-sharing of financial responsibilities between the State Council and local governments in accordance with their portfolios for basic education, and (c) the specific co-sharing of financial responsibility for basic education in rural areas between the State Council and local governments, with given ratios depending on needs (Article 44). Thus the responsibility for financing basic education is stipulated to shift upwards from governments at the county level or below to higher units of governance (i.e., central and provincial governments).

Fourth, the revised law introduces the state's legal accountability. In the revised law, the NPC clearly specifies who is legally responsible for what duties and what might be illegal (Articles 52-54, 56-59). It further identifies the consequences that the State Council or governments of other levels might face if they fail to ensure sufficient financing for basic education: The State Council or governments of a higher level would ask them to rectify the situation within a given period, and government officials in charge would be given administrative punishment, or be dismissed in serious cases (Articles 9, 51). Anyone who violates the revised law to the extent of committing criminal acts would be prosecuted (Article 60).

\section{Institutionalizing the Principle of Balanced Development}

To reduce or eradicate disparities, the revised Basic Education Law advocates a principle of "balanced development" (junheng fazhan), which is expected to help create a fair educational system, extending the level of equity beyond the right to equal access to basic education to equal opportunity to learn in schools with similar standards. To institutionalize 
this principle within governments of various levels, the revised law stipulates three major policies: (a) shifting financial responsibilities to governments of higher units, (b) reducing gaps in the teaching force between areas, and (c) improving physical school conditions in rural areas.

The first policy for balanced development is to shift responsibilities towards governance of higher units. In particular, governments are responsible for providing basic education for children from families with financial difficulties, children who suffer from any form of handicap, and juveniles in prison who have not finished basic education (Articles 6, 19, 21). Governments above the county level must establish special funds to support basic education in rural and minority areas, and governments at the county level or below are legally obligated to ensure that these funds are used for basic education and are not diverted (Article 47). Governments of all levels are required to help eligible children from poor families by providing them with free textbooks and subsidizing their accommodations in boarding schools (Article 44). In response, the State Council earmarked RMB1.43 billion for the textbooks of 30 million students in 22 provinces in the spring term of 2007.

Moreover, the State Council and governments above the county level are accountable for allocating resources to improve the conditions and facilities of weak schools, and developing measures to ensure the provision of basic education in rural areas and ethnic minority communities, particularly for poor and handicapped children (Article 6). They are required to establish schools or classes for ethnic minority children in economically developed areas (Article 18). They also are legally responsible for reducing disparities at the local level by closing gaps in conditions and facilities between schools, forbidding the classification of schools at the local level into keypoint and non-keypoint schools, and banning the streaming of students at the school level into keypoint and non-keypoint classes (Article 22). Moreover, to enforce compulsory schooling at the local level, the revised law stipulates that measures must be introduced to help ease the difficulties that hinder eligible students from receiving compulsory schooling and guard against dropout (Article 13).

To protect the rights of the weak to access basic education, the revised law requires governments above the county level to establish both special schools or classes for children with disabilities of various types and mainstream schools to enroll students with mild disabilities who possess an ability to learn (Article 19). The per-capita public expenditure for students in special schools or classes should be higher than that for their counterparts in mainstream schools (Article 43). Moreover, the revised law gives legal rights to children of migrant workers (those who move from other areas and do not have household registration in host areas) to access basic education in host areas. Host governments, which, as mentioned earlier, were unwilling to pay, are stipulated to provide "equal" conditions for eligible local and migrant children in basic education, and are held responsible for providing basic education for migrant children (Article 12).

The second policy of promoting balanced development in basic education is intended to narrow the gaps in the provision and quality of teachers and teaching resources among schools within and between areas. Governments above the county level are responsible for strengthening teacher training and development; whereas county governments are responsible for the training and mobility of school principals and teachers (Article 32). In particular, the revised law requires governments of various levels to mobilize teachers in urban areas and graduates of higher education institutes to voluntarily teach in rural areas or minorities areas, and county governments must count this volunteer period as part of the teachers' official teaching experiences (Article 33). In response, the State Council piloted the policy of offering free education during the 2007-08 academic year for about 12,000 students for four years in six elite normal universities (including Beijing Normal University and East China Normal University) (Ministry of Education, Ministry of Finance, \& Ministry of Personnel, 2007). 
Students who want such free teacher training must agree to teach in a primary or secondary school for at least 10 years after graduation and must spend the first 2 years in a rural school. The Opinions also requests educational bureaucracies at various local levels to mobilize the co-sharing of excellent teachers and disseminate good teaching practices in their jurisdictions.

The third policy of balanced development is the improvement of school conditions, particularly in rural areas. Schools are required to conform to the state's basic standards (Article 16). Governments above the county level must ensure a safe environment for students by conducting regular checks on school buildings and providing immediate school maintenance and improvement if needed (Article 24). To reduce travel problems that may deter students' motivation to receive compulsory schooling, county governments are required to establish boarding schools for students who come from dispersed areas (Article 17). County governments must tilt resources for basic education towards rural schools and "weak" schools that are less competitive and often have poor facilities (boruo xuexiao) (Article 45), whereas governments above the county level are responsible for improving the conditions of "weak" schools (Article 6). To further reduce the gaps among schools, the Opinions asks local governments to promote the co-sharing of teaching resources, such as laboratory facilities, library resources, and sports arenas, among schools.

\section{A Critique of the Revised Basic Education Law in the Pursuit of Equity in Education}

The revised Basic Education Law laid down important principles and stipulated measures to rectify educational inequality arising from the mismatch between the governments' financing abilities and responsibilities and the widening disparities in basic education. Despite good intentions, the revised law is expected to confront three major, contentious issues: (a) a severe shortage of state and local government subsidies to schools, (b) deep-seated issues embedded in the problems of education (such as parents' and students' perceptions of keypoint schools), and (c) structural constraints on migrant children's opportunities to access post-compulsory education. These issues are extra-legal and cannot be solved by the revised law alone.

Questions about Local Governments' Ability to Finance Basic Education

The first contentious, extra-legal issue confronting the revised law is whether shifting financial responsibilities can improve financing for local basic education. The principle of cosharing financial responsibility compels the central government to provide more support for basic education in western and central China in three major aspects: school fees and miscellaneous fees, textbook fees, and school maintenance and improvement. It is estimated that between 2006 and 2010, the budgetary increase for rural education through such cosharing would amount to RMB 218 billion, of which 57\% would come from the central government and 43\% from local governments (Ministry of Education, 2007c). However, the revised law, as argued in this section, does not deal with core issues related to the shortage of education financing in local areas: a low national educational budget and the relatively low ability of middle and western regions to generate regional income. Without the support of strong local economies and matching taxation mechanisms it is difficult for local governments to improve their revenues and thus increase their basic education expenditures.

First, despite the increase in the state's share, the amount of national funding to local basic education on the whole is still low. Although China has significantly increased its per capita GDP by over seven-fold, from RMB 1,644 in 1990 to RMB 14,040 in 2005, the percentage of the GDP spent on public education has remained low, for example, 3\% in 1990 and 2.9\% in 2005 (Ministry of Education, et al., 2006; National Bureau of Statistics, 2006c). These rates of educational expenditure are lower than the world average (5\% in 2004) and even the average of countries with medium development (4.4\% in 2002-04) (calculated from UNESCO Institute for Statistics, 2007; United Nations Development Programme, 2006). 
Recognizing this low investment, the state pledged to raise the educational expenditure to $4 \%$ of the GDP beginning in the 1990s (e.g., Communist Party of China Central Committee, 2006), but it has not yet done so.

Second, the reduction in educational disparities is further limited by local governments' weak financial foundation, particularly in poor areas. As discussed earlier, since the early 1990s, the reform of taxation mechanisms has weakened local governments' revenues (but strengthened the state's revenues). Despite this, local governments are still expected to contribute a significant portion, $43 \%$ of RMB 218 billion, to implement the fiveyear plan for "two exemptions and one subsidy." However, the revised Basic Education Law did not address this issue because it was beyond its remit.

If local governments cannot increase their "piece of the pie" (i.e., their tax revenue), another possible way to obtain more revenue is to make the pie larger by improving local economies. However, since the economic reform and opening up to the world in the late 1970s, the economic developments of the middle and western regions have significantly lagged behind those of the eastern region, and the gaps between the former and latter (such as the share of the national GDP and the per-capita GDP) are widening rather than narrowing.

The weak financial foundation of local governments, in turn, weakens their ability to finance basic education in their jurisdictions. Although rich governments do not necessarily provide strong financial support to basic education, poor governments are less likely to be able to provide strong support. At the provincial level, coastal areas, such as Shanghai, had more resources for basic education than poor areas in middle and western China, such as Henan and Guizhou, respectively (see Table 1). Even worse was the widening of this regional gap in the ratio between the highest and lowest expenditure of budgetary appropriation for education per student in primary and junior secondary education.

(Table 1 about here.)

At the county level and below, the disparity in resource allocation for basic education is further widened by the variation in individual counties and townships' financial ability. As compared with their wealthier counterparts, counties and townships with low GDPs have fewer resources to support basic education. Governments of poor counties, townships, and villages--as well as their schools--often borrow money from banks and land developers to rebuild dangerous school buildings, improve school facilities, and maintain daily operations. It has been estimated that by 2004 basic education-related debt across the country had accumulated to RMB 50 billion, and $88 \%$ of the regions had not cleared their debts (Zhou, 2005). At the school level, debts ranged from half a million to several million Chinese dollars, and many schools cannot pay back their loans. To help release schools from debt, the Ministry of Education (2007b) suggested that provincial governments take the lead in coordinating and setting the ratio of financial responsibilities among local governments in their jurisdictions. However, this suggestion goes back to the question of local governments' ability to finance basic education.

\section{Expected Continuous Educational Disparities across the Nation}

The second controversial, extra-legal issue confronting the revised Basic Education Law is whether it can eradicate disparities in basic education. The revised law reiterates a policy of admission by catchment areas without examination, stipulates "balanced development" in basic education, and prohibits the separation between keypoint and nonkeypoint schools or classes. The revised law and related measures intended to rectify problems of educational disparities may be fruitless because they do not deal with three major, deep-seated problems: unequal opportunity of access to similar educational facilities, unequal participation in education, and the complexity of keypoint schools.

First, similar to its predecessor, the revised law can reduce the urban-rural disparity in the quantitative provision of school places, but it cannot ensure students' equal opportunity to 
study in learning environments and educational facilities with similar standards. The revised law stipulates giving more subsidies to rural schools and encouraging good teachers to teach there. This may help, but not significantly improve the school conditions or attract good teachers, particularly in poor local areas, owing to their weak income-generating ability and the low national educational budget, as shown earlier. In particular, the revised law does not address the policy discrimination against rural students arising from new national standards, according to which rural students have less human resource support, because the student-staff ratios of both primary and junior-secondary schools in rural areas are set to be larger than those in cities (see Table 2). Many rural schools cannot afford to pay teachers' allowances to enhance their incentives or to organize school activities, for example, to celebrate Teachers Day as their counterparts in urban areas did (Han \& Tan, 2008). Moreover, as in rural America (Jimerson, 2003), low-paying, rural areas in China cannot keep good teachers and recruit urban teachers, owing to the widening differences in their salaries and working conditions. The household registration policy further reduces urban teachers' willingness to serve in rural areas, because housing, health care, social welfare, and education for their children are still tied to their original (urban) domicile (J. Chen \& Chen, 2008).

(Table 2 about here.)

Second, the revised law is unlikely to reduce urban-rural disparities in terms of students' opportunity to access subsequent educational levels. Although the overall average admission rate of junior-secondary education has been very high (such as 95\% in 2005) (Ministry of Education, 2006a), about $10 \%$ of primary school graduates in rural areas were unable to receive junior-secondary education for various reasons, including a heavy financial burden on parents (Yuan, 2005).

Third, the revised law tries to reduce inter-school and intra-school disparities by forbidding keypoint schools and classes at the compulsory-schooling level (Article 22). However, such a prohibition is likely to fail because the revised law does not address the complex issues behind the high demand for keypoint schools (or classes). For example, the revised law does not address the socio-cultural issue related to people's preference for "brandname" schools. In contemporary China, many people believe that keypoint schools have better conditions that attract good teachers and good students, and that students in good schools have a greater chance of getting higher scores on public examinations and thus are more likely to gain access to a university education and therefore better jobs and life chances (Law, 2006). To parents and students, whether good schools are officially called keypoint does not matter much.

While the revised law forbids the term "keypoint," state and local governments continue to allow and even encourage schools to compete to become "demonstration" schools that serve as models for other schools. In this competition, former keypoint schools have better infrastructures, stronger teaching teams, and higher student performance than ordinary schools. While many schools that were once keypoint are now called demonstration schools, rarely do ordinary schools become demonstration schools. In other words, already wellestablished schools are likely to continue enrolling students from within and outside their school networks, whereas other schools are likely to continue admitting the remaining tiers of students.

\section{Continuing Discriminatory Practices against Migrant Workers' Children}

The third controversial, extra-legal issue challenging the revised Basic Education Law is the continuation of discriminatory practices against the upward social mobility of migrant workers' children. The household registration policy continues to skew educational opportunities and leaves migrant children lagging behind their local counterparts at two important starting lines: compulsory schooling and post-compulsory education. 
To some extent, the 2006 revised law improved migrant students' opportunities to access compulsory schooling in host areas by asking host local governments to take financial responsibility. Nevertheless, this is limited by local governments' financing capability and local public schools' capacity. For example, in Guangzhou, in 2008-09 only one third of 400,000 migrant children were enrolled in public schools, and each of them was still required to pay the school-place rental fee set by the local price bureau: RMB753 per semester in primary school and RMB900 in junior-secondary school (X. M. Chen, 2009). The absorption of migrant children into public schools is exacerbated by their increasing number across the country, which is expected to rise from 20 million in the mid-2000s to 58 million in 2015 ( Du, 2008).

Moreover, because the revised law does not delink household registration from enrolment registration, migrant children in host areas are still deprived of equal access to local senior-secondary education. Some host areas are beginning to allow migrant children who graduate from local junior-secondary schools to apply for further studies in vocational and technical schools or institutes, but not grammar senior-secondary schools, which are the major route to university education. As a result, after graduating from primary school, many migrant children are sent back to their original domicile for junior-secondary education (Law, 2006). Thus many children face learning problems arising from differences in textbooks and materials used between original and host domiciles, which might adversely affect their performance in examinations for admission to senior-secondary schools. Among those who stay for junior-secondary education in host areas, only a small minority of migrant graduates return to their home place for senior-secondary education, and the majority stay with their parents in host areas without further education, or even jobs (R. W. Hu, Zhu, \& Du, 2008).

\section{Discussion and Conclusion: Law in the Quest for Educational Equality}

Education is a means to bolster social equity and justice, and equal educational opportunity to access education is an important means of upward social mobility. However, achieving the quantitative goal of providing basic education for all does not necessarily mean that unequal educational opportunities have been eradicated. With reference to China's compulsory schooling legislation, this article has examined two interrelated problems: the uneven distribution of public resources to schools and the inequality of students' educational opportunities. In doing so, it has identified the features and factors accounting for different forms of inequality in basic education for all in China. Unlike some studies on education and equality (e.g., Coleman, 1990; Darling-Hammond, 2007; Iannelli \& Paterson, 2007; Lynch \& Moran, 2006), this study has demonstrated that in the case of China, the state's basic education policy and loopholes in the original basic education law are major causes of inequality in compulsory schooling. The law revision reflects the China's pragmatic use of law to address specific problems in different times.

Moreover, China's case provides a useful theoretical framework for understanding the complex, dynamic relationships among law, state, and change in the pursuit of equity in society and education. As a social construct, law has three functions through which it can effect change to reduce inequality between and within regions or schools. First, law can be an agent of and vehicle for change, setting the goals and ground rules for action to tackle educational inequality. As discussed, the 1986 Basic Education Law (together with other strategies) contributed to the quantitative achievement of universalizing nine-year compulsory schooling within the relatively short period of two decades. The revised law not only mandates specific areas of change in basic education (such as a reduction in educational disparities), but also prescribes the specific duties and responsibilities of important stakeholders, particularly governments above the county level. The revised legislation 
indicates that China continues to rely on law to establish a legal framework and routes for change.

Second, law can be a regulator of state power to keep the administration under control and hold it accountable for its legally binding obligations. We have shown that the revised Basic Education Law is expected to be an important device to hold state machineries legally accountable for their behaviors and practices. The revised law can be interpreted as the national lawmaking body's verdict condemning the state for failing to protect children's rights, lacking administrative ability to enforce the law and its own regulations, and lacking measures to tackle disparities and inequality, among other problems, in basic education. According to the original law, despites its incompetence, the state did not need to take any legal responsibility. Now the revised law reshuffles the financing responsibilities of governments of various levels and provides them with a legal clarification in financial and personnel matters. In particular, the revised law imposes larger legal obligations on governments above the county level (including the State Council) for financing and allocating resources to basic education, and managing as well as supervising the implementation of basic education.

Third, law also can be used as a device of social justice to promote equity in society and education. China's lawmaking body gave the revised law a new task to ensure equality in basic education for all. Unlike the United States' No Child Left Behind Act, which was intended to narrow school achievement gaps among students (Darling-Hammond, 2007), the revised Basic Education Law in China was meant to reduce the gaps in regional financing for basic education. The revised law also is intended to rectify three major types of educational disparities (between urban and rural areas, between regions, and between and within schools) by enshrining principles of balanced development and institutionalize them by compelling the state to take more financial responsibilities, improving the quality of teachers and reallocating teaching resources, and improving school conditions in needy areas.

Despite these functions, the law as a social construct is constrained in effecting change. As Tomasic (1985) warned, it is dangerous to oversimplify the relationship between law and society and over-exaggerate the power of law to effect changes in human behaviors and social interactions that are highly complex and affected by non-legal factors, such as political forces and cultural values. Along this line, we have shown three possible interrelated, extra-legal constraints on using law to bring about change from the widening to narrowing of educational disparities in China. First, the translation of legislative change can be limited by its wider context. Law cannot be separated from other social institutions and social forces, nor is it a panacea or solution for educational, social, and/or economic inequality. Second, legislative changes often cannot be realized without the support of favorable extra-legal conditions, such as economic ones. In the case of China, despite the increase in the state's subsidies, local basic education still relies significantly on local governments' financial support. Third, culture can be a strong barrier to legislative change. For example, despite its good intention, one of the principles of balanced development, namely, banning keypoint schools or classes, goes against people's socio-cultural values and perceptions of good schools and classes. This study suggests that favorable social conditions for the use of legislation to promote equity entail the support of favorable economic conditions, political determination, societal cultures that shape and guide the behaviors and activities of people and governments, and/or the cooperation of those who interpret and enforce the law.

The revised basic education law emerged at a time when the nation's leaders were aiming to construct a harmonious and equitable society and culture, and it raises hope for promoting social justice, and for creating, maintaining, and enhancing social conditions for an equitable basic educational system in China. Whether the revised Basic Education Law 
will bring forth its intended changes remains to be seen. Similar to the previous legislation, we can expect the revised law to confront extra-legal factors that the law alone cannot solve. 
Table 1

National Average, Lowest, and Highest Per Capita Expenditures of Budgetary Appropriation for Compulsory Schooling in China (in RMB)

\begin{tabular}{|c|c|c|c|c|c|}
\hline Year & Level & $\begin{array}{l}\text { National } \\
\text { Average }\end{array}$ & $\begin{array}{l}\text { Lowest } \\
\text { Figure (place) }\end{array}$ & $\begin{array}{l}\text { Highest } \\
\text { Figure (place) }\end{array}$ & $\begin{array}{l}\text { Highest- } \\
\text { lowest Ratio }\end{array}$ \\
\hline \multirow[t]{2}{*}{$1995-96$} & Primary education & 266 & $\begin{array}{c}144 \\
\text { (Henan) }\end{array}$ & $\begin{array}{c}1,217 \\
\text { (Shanghai) }\end{array}$ & 8.5 \\
\hline & $\begin{array}{l}\text { Junior secondary } \\
\text { education }\end{array}$ & 492 & $\begin{array}{c}312 \\
\text { (Guizhou) }\end{array}$ & $\begin{array}{c}1,536 \\
\text { (Shanghai) }\end{array}$ & 4.9 \\
\hline \multirow[t]{2}{*}{ 2006-07 } & Primary education & 1,634 & $\begin{array}{c}948 \\
\text { (Henan) }\end{array}$ & $\begin{array}{c}9,410 \\
\text { (Shanghai) }\end{array}$ & 9.9 \\
\hline & $\begin{array}{l}\text { Junior secondary } \\
\text { education }\end{array}$ & 1,897 & $\begin{array}{c}1,191 \\
\text { (Guizhou) }\end{array}$ & $\begin{array}{c}10,326 \\
\text { (Shanghai) }\end{array}$ & 8.7 \\
\hline \multirow[t]{2}{*}{ 2007-08* } & Primary education & 2,207 & $\begin{array}{c}1,393 \\
\text { (Henan) }\end{array}$ & $\begin{array}{c}11,499 \\
\text { (Shanghai) }\end{array}$ & 8.3 \\
\hline & $\begin{array}{l}\text { Junior secondary } \\
\text { education }\end{array}$ & 2,679 & $\begin{array}{c}1,742 \\
\text { (Guizhou) }\end{array}$ & $\begin{array}{c}13,123 \\
\text { (Shanghai) }\end{array}$ & 7.5 \\
\hline
\end{tabular}

Note. In 2007, the state began to increase its share for financing basic education.

Sources. State Education Commission (1997) and Ministry of Education, National Bureau of Statistics, \& Ministry of Finance $(2007,2008)$. 
Table 2

Student-staff Ratios of Schools in China's Urban and Rural Areas According to New National Standards

\begin{tabular}{llll}
\hline & Cities & County/Township & Village \\
\hline Primary schools & $19: 1$ & $21: 1$ & $23: 1$ \\
Junior secondary schools & $13.5: 1$ & $16: 1$ & $18: 1$ \\
\hline
\end{tabular}

Source. State Commission Office for Public Sector Reform, Ministry of Education, \& Ministry of Finance (2001). 


\section{REFERENCES}

Anleu, S. L. R. (2000). Law and Social Change. London SAGE.

Ballantine, J. H. (2001). The Sociology of Education: A Systematic Analysis (Fifth ed.). Upper Saddle River, N.J.: Prentice-Hall.

Bilton, T., Bonnett, K., Jones, P., Tony, L., Skinner, D., Stanworth, M., et al. (2002). Introductory Sociology (Fourth ed.). Basingstoke: Palgrave Macmillan.

Chen, J., \& Chen, Y. (2008). Woguo Chengxiang Jiaoshi Liudong Shiheng De Zhidu Fenxi [Analysis on the Imbalance in Teacher Flowing Between Rural and Urban Areas in China]. Jiaoyu Fazhan Yanjiu [Research in Educational Development], 3-4, 40-43.

Chen, X. M. (2009, 24 January). Guangzhou Liudong Renkou Zinu Shangxue Jinnian Youwang Bu Jiao Jiedu Fei [Migrant Children in Guangzhou Hopefully Need Not Pay School-Place Rental Fees from This Year]. Yangcheng Wanbao [Yangcheng Evening News], p. 1.

Chu, H., \& Yang, H. (2008). Jiaoyu Gongping de Yuanze Jiqi Zhengce Hanyi [The Essence of Educational Equity and Its Policy Significance]. Jiaoyu Yanjiu [Educational Research], 336(1), 10-16.

Coleman, J. (1966). Equality of Educational Opportunity Study. Washington, D. C.: US Department of. Health, Education \& Welfare.

Coleman, J. (1975). What is Meant by an Equal Educational Opportunity? Oxford Review of Education, 1(1), 27-29.

Coleman, J. (1990). Equality and Achievement in Education. Boulder, Colo.: Westview Press.

Communist Party of China Central Committee (1985). Reform of China's Educational Structure. Beijing: Foreign Languages Press.

Communist Party of China Central Committee (2006). Guanyu Goujian Shehui Zhuyi Hexie Shehui Ruogan Zhongda Wenti Jueding [A Decision Concerning Several Important Questions about the Construction of Socialist Harmonious Society]. Beijing: People's Press.

Communist Party of China Central Committee and State Council (1993). Zhongguo Jiaoyu Gaige He Fazhan Gangyao [The Scheme for the Reform and Development of Education in China] Zhonghua Renmin Gongheguo Jiaoyufa, Yiwu Jiaoyufa, Jiaoshifa [The Education Law, Basic Education Law and Teachers Law of the People's Republic of China] (pp. 35-57). Beijing: China Law Publishing House.

Dahrendorf, R. (1975). The New Liberty: Survival and Justice in a Changing World. London: Routledge \& Kegan Paul.

Dalal, P. (2005). Law as an Instrument of Social Change Retrieved 5 November, 2007, from http://www.naavi.org/praveen_dalal/law_jan8.htm

Darling-Hammond, L. (2007). Race, Inequality and Educational Accountability: The Irony of No Child Left Behind. Race Ethnicity and Education, 10(3), 245 - 260.

Deng, X. P. (1977a). Guanyu Kexue He Jiaoyu Gongzuo De Jidian Yijian [Some Comments on Work in Science and Education]. In Central Committee of Communist Party of China Document Editorial Commission (Ed.), Deng Xiaoping Wenxuan, 1975-1982 [Selected Work of Deng Xiaoping, 1975-1982] (pp. 45-55). Beijing: Renmin Publication House.

Deng, X. P. (1977b). Zunzhong Zhizhi Zhuzhong Rencai [Respect Knowledge, Respect Trained Personnel]. In Central Committee of Communist Party of China Document Editorial Commission (Ed.), Deng Xiaoping Wenxuan, 1975-1982 [Selected Work of Deng Xiaoping, 1975-1982] (pp. 37-38). Beijing: Renmin Publication House.

Deng, X. P. (1978). Zaiquanguo Jiaoyu Gongzuo Huiyi Shang De Jianghua [Speech at the National Conference on Education]. In Central Committee of Communist Party of 
China Document Editorial Commission (Ed.), Deng Xiaoping Wenxuan, 1975-1982 [Selected Work of Deng Xiaoping, 1975-1982] (pp. 100-107). Beijing: Renmin Publication House.

Deng, X. P. (1991). Shicha Shanghai Shi De Tanhua [Remarks Made During An Inspection Tour of Shanghai]. In Central Committee of Communist Party of China Document Editorial Commission (Ed.), Deng Xiaoping Wenxuan, 1983-1992 [Selected Work of Deng Xiaoping, 1983-1992] (pp. 366-367). Beijing: Renmin Publication House.

Dittmer, L. (2003). Leadership Change and Chinese Political Development. China Quarterly, 176, 903-925.

Donnelly, J., \& Howard, R. E. (1988). Assessing National Human Rights Performance: A Theoretical Framework. Human Rights Quarterly, 10(2), 214-248.

Du, X. L. (2008). Liudong Renkou Zinu Yiwu Jiaoyu Wenti Pouxi [On the Compulsory Education for the Children of the Rural Workers in Chinese Cities]. Jiaoyu Fazhan Yanjiu [Research in Educational Development], 1, 50-54.

Gopinathana, S., \& Altbach, P. G. (2005). Rethinking Centre-Periphery. Asia Pacific Journal of Education, 25, November(2), 117-123.

Han, T. Y., \& Tan, H. X. (2008, 23 April). Nongcun Jiaoshi Geng Gai Pingpin Fenli [The Employment and Appraisal of Teachers in Rural Areas Should be Separated]. Zhongguo Jiaoshibao [China Teachers Newspaper], p. 16.

Hazard, W. R., \& Rosenblum, V. G. (1976). Education, the Law, and Social Change. Education and Urban Society, 8(3), 259-266.

Horton, P. B., \& Hunt, C. L. (1984). Sociology. Auckland: McGraw-Hill.

Hu, J. T. (2003). Zai Sange Daibiao Yantaohui Shangde Jianghua [Speech at the Symposium on the "Three Represents"]. In D. Y. Shen \& L. S. Cheng (Eds.), Hu Jintao Tongzhi Qiyi Zhongyao Jianghua Xueji Duben [A Study Guide for the Speech of Hu Jiantao at the Symposium on the "Three Represents"] (pp. 1-18). Beijing: Communist Party of China Central Committee Party School Press.

Hu, J. T. (2006). Laogu Shuli Shehui Zhuyi Rongruguan [To Consolidate the Socialist Framework for Honours and Disgraces]. Qiushi [Seeking Truth], 9, 1.

Hu, J. T. (2007). Gaoju Zhongguo Tese Shehui Zhuyi Weida Qizhi Wei Duoqu Quanmian Jianshe Xiaokang Shehui Xin Shengli Er Fendou Zai Zhongguo Gongchandang Di Shiqici Quanguo Daibiao Dahui Shang De Baogao [Hold High the Great Banner of Socialism with Chinese Characteristics and Strive for New Victories in Building A Moderately Prosperous Society in All Respects -- Report to the Seventeenth National Congress of the Communist Party of China on Oct. 15, 2007]. Beijing: People's Press.

$\mathrm{Hu}$, J. T. (2008, 18 March). Zai Shiyijie Quanguo Renda Yici Huiyi Shang De Jianghua [Speech at the First Session of the 11th National People's Congress]. Renmin Ribao [People's Daily], p. 1.

Hu, R. W., Zhu, T., \& Du, X. L. (2008). Shanghai Liudong Renkou Zinu Yiwu Jiaoyu Wenti Hou Chulu Yanjiu [The Way out for Migrant Workers' Children after Compulsory Education in Shanghai]. Jiaoyu Fazhan Yanjiu [Research in Educational Development], 3-4, 15-18.

Iannelli, C., \& Paterson, L. (2007). Education and social mobility in Scotland. Research in Social Stratification and Mobility, 25(3), 219-232.

Jary, D., \& Jary, J. (1999). Dictionary of Sociology (Second ed.). Glasgow: HarperCollins Publishers.

Jencks, C. (1972). Inequality: A Reassessment of the Effect of Family and Schooling in America. New York: Basic Books.

Jiang, Z. M. (1997). Gaoju Dengxiaoping Lilun Weida Qizhi Ba Jianshe yao Zhongguo Tuse Shehui Zhuyi Shiye Guanmian Tuixiang 21 Shiji [To Raise the Flag of Deng 
Xiaoping's Theory and to Push the Construction of the Socialist Business with Chinese Characteristics into the 21st Century]. Beijing: Renmin Press.

Jiang, Z. M. (2002). Jiang Zemin Lun Yao You Zhongguo Tese Shehuizhuyi: Zhuantizhaibian [Selected Speeches of Jiang Zemin on Socialism with Chinese Characteristics]. Beijing: Communist Party of China Central Committee Document Publishing House.

Jimerson, L. (2003). The Competitive Disadvantage: Teacher Compensation in Rural America. Arlington, VA: Rural Schools and Community Trust.

Kwong, J. (2004). Educating Migrant Children: Negotiations between the State and Civil Society. China Quarterly, 180, 1073-1088.

Law, W.-W. (1999). New Rules of the Game in Education in the People's Republic of China: Education Laws and Regulations (Guest Editor's Introduction). Chinese Education \& Society, 32(3), 3-8.

Law, W.-W. (2002). Legislation, Education Reform and Social Transformation: The People's Republic of China's Experience. International Journal of Educational Development, 22(6), 579-602.

Law, W.-W. (2006). Education Reform for National Competitiveness in a Global Age: The Experience and Struggle of China. In K. Mazurek \& M. Winzer (Eds.), Schooling Around the World: Debates, Challenges, and Practices (pp. 68-103). Boston, MA.: Pearson Allyn \& Bacon.

Law, W.-W. (2007). Legislation and Educational Change: The Struggles for Social Justice and Quality in China's Compulsory Schooling. Education and the Law, 19(3-4), 177199.

Le Grand, J. (1982). The Strategy of Equality: Redistribution and the Social Services. London: Allen and Unwin.

Levin, H. M. (1976). Educational Opportunity and Social Inequality in Western Europe. Social Problems, 24(2), 148-172.

Lewis, J. W., \& Xue, L. T. (2003). Social Change and Political Reform in China: Meeting the Challenge of Success. China Quarterly, 176, 926-942.

Li, J. F. (2007). Socialist Rule of Law with Chinese Characteristics. Issues \& Studies, 43(1), $115-157$.

Li, L. C. L. (2006). Differentiated Actors: Central-Local Politics in China's Rural Tax Reforms. Modern Asian Studies, 40(1), 151-174.

Li, P. (1986). Guanyu Zhonghua Renmin Gongheguo Yiwu Jiaoyufa Caoan De Shuoming [An Explanatory Note on the Draft of the Basic Education Law of the People's Republic of China]. Beijing: National People's Congress.

Liu, D., \& Wang, S. H. (2004, 23 February). Weinongmingong Zinu Jiuxue Pupinglu [To Make for Migrant Children's Road to Education Straight] Retrieved 15 May, 2007, from http://210.51.8.60/home/news/society/200403/02/210559.html

Liu, Y. R. (2003). Jichu Jiaoyu Jingfei De Baozhang [To Ensure the Financing for Basic Education]. In National Academy of Education Administration (Ed.), Jichu Jiaoyu Xinshidian [New Perspectives on Basic Education] (pp. 212-241). Beijing: Educational Science Press.

Lynch, K., \& Moran, M. (2006). Markets, Schools and the Convertibility of Economic Capital: The Complex Dynamics of Class Choice. British Journal of Sociology of Education, 27(2), 221-235.

Mackerras, C. (1995). China's Minority Cultures. Melbourne: Longman.

Ministry of Education (2006a, 4 July). 2005 Nian Guanguo Jiaoyu Shiye Fazhan Tongji Gongbao [Statistical Report on Educational Achievements and Developments in China in 2005]. Zhongguo Jiaoyubao [China Education Daily], p. 2. 
Ministry of Education (2006b). Guanyu Guanche Yiwu Jiaoyufa Jinyibu Guifan Yiwu Jiaoyu Banxue Xingwei De Ruogan Yijian [The Opinions Concerning the Implementation of the Basic Education Law to Further Regulate School Practices in Basic Education] (No. Jiaoji 2006-19). Beijing: Ministry of Education.

Ministry of Education (2007a, 7 June). 2006 Nian Guanguo Jiaoyu Shiye Fazhan Tongji Gongbao [Statistical Report on Educational Achievements and Developments in China in 2006]. Zhongguo Jiaoyubao [China Education Daily], p. 2.

Ministry of Education (2007b). Guanyu Jinyibu Zuohao Nongcun Yiwu Jiaoyu Jingfei Baozhang Jizhi Gaige Youguan Gongzuo De Tongzhi [A Circular Concerning Further Improvement on the Reform to Ensure the Mechanisms of Financing Rural Basic Education]. Beijing: Ministry of Education.

Ministry of Education (2007c). Jieshao Nongcun Yiwu Jiaoyu Jingfei Baozhang Jizhi Gaige De Youguan Qingkuang [Report on the Progress of the Reform of Mechanisms to Ensure Financing Rural Education]. Beijing: Ministry of Education.

Ministry of Education, Ministry of Finance, \& Ministry of Personnel (2007). Jiaoyubu Zhishu Shifan Daxue Shifansheng Mianfei Jiaoyu Shishi Banfa Shixing [A Pilot Scheme for Free Education for Students in Normal Universities Directly Under the Ministry of Education]. Beijing: Ministry of Education.

Ministry of Education, National Bureau of Statistics, \& Ministry of Finance (2006, 31 December). 2005 Nian Quanguo Jiaoyu Jingfei Zhixing Qingkuang Tongji Gonggao [Report on the Implementation of the National Educational Expenditure of the People's Republic of China, 2005]. Zhongguo Jiaoyubao [China Education Daily], p. 2.

Ministry of Education, National Bureau of Statistics, \& Ministry of Finance (2007, 29 December). 2006 Nian Quanguo Jiaoyu Jingfei Zhixing Qingkuang Tongji Gonggao [Report on the Implementation of the National Educational Expenditure of the People's Republic of China, 2006]. Zhongguo Jiaoyubao [China Education Daily], p. 2.

Ministry of Education, National Bureau of Statistics, \& Ministry of Finance (2008, 1 December). 2007 Nian Quanguo Jiaoyu Jingfei Zhixing Qingkuang Tongji Gonggao [Report on the Implementation of the National Educational Expenditure of the People's Republic of China, 2007]. Zhongguo Jiaoyubao [China Education Daily], p. 2.

Nagel, S. S. (Ed.). (1970). Law and Social Change. Beverly Hills, CA: SAGE.

Nash, R. (2004). Equality of Educational Opportunity: In defence of a Traditional Concept. Educational Philosophy and Theory, 36(4), 361-377.

National Bureau of Statistics (2006a). 2005 Nian Quanguo 1\% Renkou Chouyang Diaocha Zhuyao Shuju Gongbao [Report on the 1\% Population Census, 2005]. Beijing: National Bureau of Statistics.

National Bureau of Statistics (2006b). Shiwu Shiqi Woguo Jingji Shehui Fazhan Qu De Juda Chengjiu [The Remarkable Achievements in Economic and Social Developments of China During the 10th Five-Year Plan Period (2000-2005)]. Beijing: National Bureau of Statistics.

National Bureau of Statistics (2006c). Zhongguo Tongji Nianjian, 2006 [China Statistical Yearbook, 2006]. Beijing: China Statistical Publishing House.

National Congress of the Communist Party of China (2002). Zhongguo Gongchandang Zhangcheng [The Constitution of Communist Party of China]. Beijing: People's Press. National People's Congress (1986). Zhonghua Renmin Gongheguo Yiwu Jiaoyufa [The Basic Education Law of the People's Republic of China] Zhonghua Renmin Gongheguo Jiaoyufa, Yiwu Jiaoyufa, Jiaoshifa [The Education Law, Basic Education Law and 
Teachers Law of the People's Republic of China] (pp. 1-13). Beijing: China Law Publishing House.

National People's Congress (1991). Zhonghua Renmin Gongheguo Weichengnianren Baohufa [Law on the Protection of Minors of the People's Republic of China]. Beijing: China Law Publishing House.

National People's Congress Standing Committee (1958). Zhonghua Renmin Gongheguo Hukou Dengji Tiaoli [The Regulations on the Domicile Registration of the People's Republic of China]. Beijing: National People's Congress.

Postiglione, G. A., Jiao, B., \& Gyatso, S. (2005). Education in Rural Tibet: Development, Problems and Adaptations China: An International Journal, 3(1), 1-23.

Project Team of a Case Study on Key Educational Policy in Transitional China (Ed.). (2005). Suoxiao Chaju: Zhongguo Jiaoyu Zhengce De Zhongda Mingti [Narrowing the Gap: A Key Issue in China's Educational Policies]. Beijing: People's Education Press.

Research Project on Compulsory Education Development in China (Ed.). (2006). Zhongguo Yiwu Jiaoyu Fazhan Yanjiu Baogao [Reports on Compulsory Education Provision in China]. Beijing: Zhongguo Minzhufazhi Publishing House.

State Commission Office for Public Sector Reform, Ministry of Education, \& Ministry of Finance (2001). Guanyu Zhiding Zhongxiaoxue Jiaozhigong Pinzhi Biaozhun Yijian De Tongzhi [Circular Concerning the Standards for the Establishment of Teaching and Non-teaching Staff of Primary Schools and Secondary Schools]. Beijing: State Council.

State Council (1994). Guanyu Zhongguo Jiaoyu Gaige He Fazhan Gangyao [An Opinion Concerning the Implementation of the Scheme for the Reform and Development of Education in China] Zhonghua Renmin Gongheguo Jiaoyufa, Yiwu Jiaoyufa, Jiaoshifa [The Education Law, Basic Education Law and Teachers Law of the People's Republic of China] (pp. 58-77). Beijing: China Law Publishing House.

State Council (2002a). Guanyu Wanshan Nongcun Yiwu Jiaoyu Guanli Tizhi De Tongzhi [Circular Concerning the Improvement on the Administrative System for Basic Education in Rural Areas]. In China Education Yearbook Editorial Board (Ed.), Zhongguo Jiaoyu Nianjian 2003 [China Education Yearbook, 2003]. Beijing: People's Education Press.

State Council (2002b). Zhongguo Renkou Pucha Ziliao 2000 [National Population Census, 2000]. Beijing.

State Council (2004). Guowuyuan Guanyu Tuijin Ziben Shichang Gaige Fazhande Jiutiao Yijian [State Council's Nine Suggestions Concerning the Promotion of Capital Market] (No. 1992-68). Beijing: State Council.

State Council (2005). Shenhua Nongcun Yiwu Jiaoyu Jingfei Baozhang Jizhi Gaige De Tongzhi [A Circular Concerning the Deepening of the Reform in Mechanisms to Ensure the Financing for Basic Education in Rural Areas]. Beijing: State Council.

State Education Commission (1997, 13 October). 1996 Nian Quanguo Jiaoyujingfei Zhixingqingkuang Tongji Gonggao [National Educational Expenditure of the People's Republic of China, 1996]. Zhongguo Jiaoyubao [China Education Daily], p. 2.

Summers, R. S., Campbell, A. B., \& Hubbard, G. F. (1974). Law and Social Change. Boston: Ginn.

Tang, W. F. (2001). Political and Social Trends in the Post-Deng Urban China: Crisis or Stability? China Quarterly, 168, 890-909.

Tomasic, R. (1985). The Sociology of Law London: SAGE.

UN Millennium Project (2005). Toward Universal Primary Education: Investments, Incentives, and Institutions. London: Earthscan. 
UNESCO (1990). World Declaration on Education For All: Meeting Basic Learning Needs. Paris: UNESCO.

UNESCO (2007). Education for All Global Monitoring Report 2008 - Education for All by 2015: Will We Make It? Paris: UNESCO.

UNESCO Institute for Statistics (2007). Global Education Digest 2006: Comparing Education Statistics Across the World. Montreal: UNESCO Institute for Statistics.

United Nations (1948). Universal Declaration of Human Rights. Retrieved May 9, 2008, from http://www.un.org/Overview/rights.html

United Nations Development Programme (2006). The 2006 Human Development Report (Beyond Scarcity: Power, Poverty and the Global Water Crisis). New York, N.Y.: United Nations Development Programme.

Wang, Z. M. (2000). The Developing Rule of Law in China. Harvard Asia Quarterly, 4(4). Retrieved from http://www.asiaquarterly.com/content/view/88/40/

Wen, H. (2007). Nongmin Gong Zinu Yiwu Jiaoyu Pingdeng Quan -- Wenti Yu Falu Baozhan [Equal Rights to Compulsory Education of Migrant Workers' Children]. Guojia Xingzheng Xueyuan Xuebao [Journal of China National School of Administration], 2, 76-79.

World Bank (2002). Millennium Development Goals 2002. Washington, D. C.: World Bank.

Wu, X. G., \& Treiman, D. J. (2003). The Household Registration System and Social Stratification in China: 1955-1996. Los Angeles: California Center for Population Research.

Yang, H. (2006). Zhongguo Shaoshu Minzhu Jiaoyu Shiye De Xin Fazhan [The Achievement and Problems about the Development of Chinese Ethnic Minorities' Population]. In S. Y. Hao \& X. E. Wang (Eds.), Zhongguo Minzhu Fazhan Baogao 2001-2006 [Report on the Development of Ethnic Minorities in China, 2001-2006] (pp. 148-165). Beijing: Social Sciences Academic Press.

Yang, X. S. (2005). Kaowen Zhongguo Jiaoyu [Interrogating Education in China]. Shanghai: Wenhui Press.

Yu, X. L. (2004). Zhongguo Jiaoyu De Chengxiang Chayi: Yizhong Wenhua Zai Shengchan Xianxiang De Fenxi [Urban-Rural Disparities in China's Education: An Analysis of the Cultural Reproduction Phenomenon]. Beijing: Educational Science Press.

Yuan, Z. G. (2005). Yanjiu Zhu Baogao [A General Report on the Issue]. In Project Team of a Case Study on Key Educational Policy in Transitional China (Ed.), Suoxiao Chaju: Zhongguo Jiaoyu Zhengce De Zhongda Mingti [Narrowing the Gap: A Key Issue in China's Educational Policies] (pp. 1-84). Beijing: People's Education Press.

Zhai, B. (2008). Shuli Kexue de Jiaoyu Junheng Fazhanguan [Establishing Scientific Outlook on Educational Balanced Development]. Jiaoyu Yanjiu [Educational Research], 336(1), 3-9.

Zhang, Q., Zhang, H., Zhong, K. B., Zhu, Q., \& Su, F. (2004). Nongcun Yiwu Jiaoyu: Shuifei Gaige Xia De Zhengce Zhixing [Basic Education in Rural China: Its Policy Implementation and Taxation Reform]. Beijing: China Social Sciences Publishing House.

Zhang, T. D., \& Zhao, M. X. (2006). Universalizing Nine-Year Compulsory Education For Poverty Reduction in Rural China. International Review of Education, 52(3-4), 261286.

Zhou, J. L. (2005). Yiwu Jiaoyu Jiqi Caizheng Zhidu Yanjiu [A Study of Basic Education and its Financial System]. Beijing: Economic Science Press.

Ziegel, J. S. (Ed.). (1973). Law and Social Change. Toronto, Ontario: Osgoode Hall Law School, York University. 